\title{
Towards the preparation of synthetic outer membrane vesicle models with micromolar affinity to wheat germ agglutinin using a dialkyl thioglycoside
}

\author{
Dimitri Fayolle ${ }^{1}$, Nathalie Berthet ${ }^{\ddagger 2}$, Bastien Doumeche ${ }^{\ddagger 1}$, Olivier Renaudet ${ }^{2}$, \\ Peter Strazewski ${ }^{1}$ and Michele Fiore ${ }^{*}, \ddagger 1$
}

\author{
Full Research Paper \\ Address: \\ ${ }^{1}$ Institut de Chimie et Biochimie Moléculaires et Supramoléculaires, \\ Université de Lyon, Claude Bernard Lyon 1, 43 blvd du 11 novembre \\ 1918, 69622 Villeurbanne Cedex, France and ${ }^{2}$ Univ. Grenoble Alpes, \\ CNRS, DCM UMR 5250, F-38000 Grenoble, France \\ Email: \\ Michele Fiore* - michele.fiore@univ-lyon1.fr \\ * Corresponding author $\ddagger$ Equal contributors \\ Keywords: \\ glycolipids; outer membrane vesicles; synthetic vaccines
}

\author{
Beilstein J. Org. Chem. 2019, 15, 937-946. \\ doi:10.3762/bjoc. 15.90 \\ Received: 10 December 2018 \\ Accepted: 02 April 2019 \\ Published: 17 April 2019 \\ Associate Editor: K. N. Allen \\ (c) 2019 Fayolle et al.; licensee Beilstein-Institut. \\ License and terms: see end of document.
}

\begin{abstract}
A series of alkyl thioglycosides and alkyl thiodiglycosides bearing glucose and $N$-acetylglucosamine residues were prepared by thiol-ene coupling in moderate to good yields (40-85\%). Their binding ability towards wheat germ agglutinin was measured by competitive enzyme-linked lectin assays. One of the synthetic compounds presenting two GlcNAc units showed the highest inhibitory effect of this study with an $\mathrm{IC}_{50}$ of $11 \mu \mathrm{M}$ corresponding to a 3182 -fold improvement compared to GlcNAc. These synthetic molecules were used to produce giant vesicles, alone or in mixture with phospholipids, mimicking bacterial outer membrane vesicles (OMV) with potential antiadhesive properties.
\end{abstract}

\section{Introduction}

Outer membrane vesicles (OMV) [1], lipid bilayer vesicles released from the outer membrane of Gram-negative bacteria, are considered today as attractive candidates for vaccine delivery. However, they have some disadvantages, they are not easy to produce and are difficult to characterize [2,3]. Moreover, toxic lipopolysaccharides (LPS) present in the outer membrane of most of Gram-negative bacteria prevent the medical use of OMV from natural sources [4]. Licensed vaccines based on crude OMV are currently available to contribute to the prevention and to control at least twenty-five infections including pulmonary ones [5]. Developing synthetic vaccines against cancer
[6,7] or Gram-negative bacteria [7] are challenges for the current research in the field. Artificial OMV, composed of synthetic and non-toxic, non-immunogenic phospholipids and glycolipids are good candidates for drug or vaccine delivery. One of the most common reactions used to prepare monoalkyl glycosides is the Fisher reaction between pyranoses and fatty alcohols of different lengths [8,9]. Alkyl thioglycosides are known for their properties as co-surfactants [10] and present interesting antimicrobial activities [11], acting as glycosidase inhibitors and being resistant towards glycoside hydrolases [12,13]. Some of them have been obtained by coupling protected 
glycosyl thiolates and $n$-alkyl halides [14-16]. Moreover, mechanochemical thioglycosylation of glycosyl acetates was used for the synthesis of $n$-alkyl 1-thio- $\alpha$-D-glycosides as carbohydrate mesogens [17]. Unfortunately, the preparation of alkyl glycosides cannot be carried out with unprotected thioglycosides, implying orthogonal protection and deprotection steps in order to obtain unprotected glycolipids. We decided to investigate the formation of artificial OMV composed of long chain alkyl thioglycosides synthesized by the photoinduced radical addition of thiols to alkenes - known as thiol-ene coupling, TEC - a very efficient metal-free click reaction $[18,19]$. We prepared $n$-alkyl 1 -thio- $\beta$-D-glycosides from unprotected sugar anomeric thiols, commercial $n$-alkenes and one synthetic lipophilic scaffold presenting two reactive alkenyl ends. Although thiyl-radical-mediated reactions have been extensively investigated for the preparation of carbohydrate derivatives [20] and some dithioether phospholipid and glycolipid analogues $[21,22]$, no examples were reported for the synthesis of $n$-alkyl thioglycosides by using thiol-ene coupling $[18,19]$. In addition to its high efficiency and selectivity, the TEC reaction does not require any metal, a key feature for the preparation of potential vaccines.

\section{Results and Discussion Preparation of alkyl glycosides from unprotected sugars and lipophilic scaffolds}

Thioglycolipids are not native in OMV [1], but present several advantages compared to natural and synthetic glycolipids, linked by a chemically and enzymatically non-stable acetal function. Owing to their straightforward access, and the stability of thioether conjugates, 1-thio- $\beta$-D-glucopyranose (1a, Figure 1), and 2-acetamido-2-deoxy-1-thio- $\beta$-D-glucopyranose (1b, Figure 1) have been selected for this study and were prepared as previously reported [23]. Commercially available 1-decene (2a) and 1-tetradecene (2b) were selected for the synthesis of $n$-alkyl 1-thio- $\beta$-D-glycosides (3-5, Scheme 1), under UV-A irradiation $\left(\lambda_{\max } 365 \mathrm{~nm}\right)$, in the presence of the photoinitiator 2,2-dimethoxy-2-phenylacetophenone (DPAP).

The lipophilic scaffold hepta-1,6-dien-4-yl tetradecanotate (6, Scheme 2) was obtained from hepta-1,6-dien-4-ol and served for the preparation of compounds 7 and 8. Hepta-1,6-dien-4-ol was prepared according to experimental procedures previously reported by others $[24,25]$, then the myristoyl group $\left(\mathrm{C}_{14: 0}\right)$ was<smiles>OC[C@H]1O[C@H](S)[C@@H](O)[C@H](O)[C@H]1O</smiles>

1a<smiles>NC(=O)N[C@H]1[C@H](S)O[C@H](CO)[C@H](O)[C@H]1O</smiles>

$1 \mathrm{~b}$

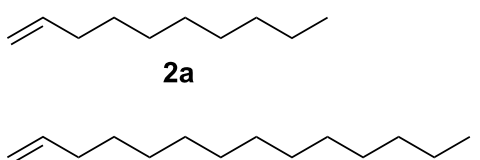

2b

Figure 1: Structure of the $\beta$-thiols $\mathbf{1 a}$ and $\mathbf{1 b}$ and of the commercial alkenes $\mathbf{2 a}$ and $\mathbf{2 b}$.<smiles>[Y]C1[C@H](O)[C@H](O)[C@@H](CO)O[C@@H]1S</smiles>

1a, $Y=O H, G l c$

1b, $Y=$ NHAc, GIcNAc

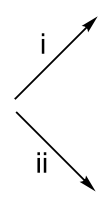

RS<smiles>[R5]CCCCNCCCCC</smiles>

3, $\mathrm{R}=\mathrm{Glc}, n=1,77 \%$

4, $\mathrm{R}=\mathrm{Glc}, n=5,55 \%$

RS $\quad$\begin{tabular}{l} 
5, R $=$ GIcNAc, $n=5,85 \%$ \\
\hline
\end{tabular}<smiles>CC(=O)O</smiles>

$7, \mathrm{R}=\mathrm{Glc}, 75 \%$

8, $R=$ GlcNAc, $40 \%$

Scheme 1: Synthesis of the $n$-alkyl thioglycosides $\mathbf{3 - 5 , 7}$ and $\mathbf{8}$. Detailed reaction conditions are reported in the experimental part; i) 1a or 1b ( 3 equiv), $\mathbf{2 a}$ or $\mathbf{2 b}$ ( 1 equiv), DPAP ( 0.3 equiv); ii) $\mathbf{1 a}$ or $\mathbf{1 b}$ ( 3 equiv), $\mathbf{6}$ (1 equiv), DPAP ( 0.6 equiv). TECs were performed at room temperature under UV light $\left(\lambda_{\max } 365 \mathrm{~nm}\right.$ ) for 30 min (with $\mathbf{2 a}$ and $\mathbf{2 b}$ ) or $60 \mathrm{~min}$ (with $\mathbf{6}$ ) in methanol (2a) or DMF (2b and 6); DPAP = 2,2-dimethoxy-2-phenylacetophenone.

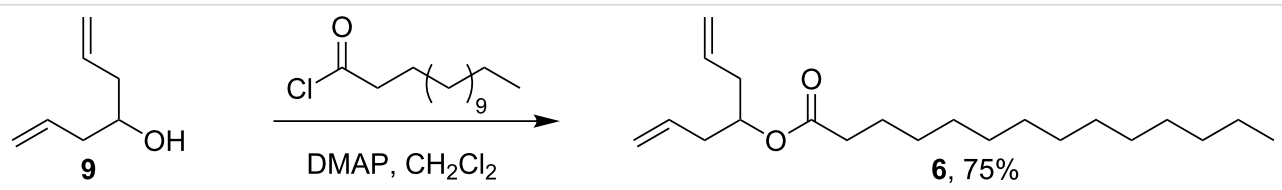

Scheme 2: Synthesis of the lipophilic scaffold 6; DMAP = N,N-dimethylaminopyridine. 
added using myristoyl chloride in the presence of DMAP (Scheme 1) [26].

\section{NMR monitoring Following the formation of thioglycosides by ${ }^{1} \mathrm{H}$ NMR analysis}

A test reaction, based on $10 \mathrm{mg}$ of $\mathbf{1 a}$, was performed in deuterated methanol (MeOD) and the formation of compound $\mathbf{3}$ was monitored by periodical ${ }^{1} \mathrm{H}$ NMR experiments, as illustrated in Supporting Information File 1, Figure S1. The signal corresponding to the double bond of $2 \mathbf{a}\left(\delta_{\mathrm{H}}=5.80-5.60 \mathrm{ppm}\right)$ disappeared together with the signals of the $\alpha$-methylene of $\mathbf{2 a}$ $\left(\delta_{\mathrm{H}}=1.96 \mathrm{ppm}\right)$. The appearance of a new doublet at $4.24 \mathrm{ppm}$ with a coupling constant $(J=9.7 \mathrm{~Hz})$ typical for an anomeric proton with $\beta$ configuration, together with a new signal at $2.60 \mathrm{ppm}$ corresponding to the $\alpha$-methylene of the newly formed thioacetal bond, indicate the formation of 3 . The aromatic protons of DPAP $\left(\delta_{\mathrm{H}}=8.00\right.$ and $7.20 \mathrm{ppm}$, not shown $)$ and the aliphatic chain signals $\left(\delta_{\mathrm{H}}=1.30\right.$ and $\left.0.75 \mathrm{ppm}\right)$ did not shift during the irradiation time. The product was not isolated and the reaction was repeated on a $50 \mathrm{mg}$ scale in methanol, giving 3 in good yields (75\%). The poor solubility of $\mathbf{2 b}$ in methanol prompted us to use $N, N$-dimethylformamide (DMF) for the synthesis of $\mathbf{4}$ and $\mathbf{5}$. Compounds $\mathbf{4}$ and $\mathbf{5}$ were isolated in good yields (55 and 75\%, respectively) [27]. The syntheses of compounds $\mathbf{7}$ and $\mathbf{8}$ were carried out in DMF as well. As substantial amounts of $\mathbf{6}$ were isolated after the reaction, indicating an incomplete conversion to $\mathbf{8}(53 \%)$, the course of the reaction was followed by ${ }^{1} \mathrm{H}$ NMR in deuterated DMF (Figure 2). The formation of $\mathbf{8}$ occurred with a progressive disappearing of the signals of the alkenyl group of $6\left(\delta_{\mathrm{H}}=5.70-5.55 \mathrm{ppm}\right)$ in one hour. The anomeric proton of the thiol $\mathbf{1 b}\left(\delta_{\mathrm{H}}=4.63 \mathrm{ppm}\right)$

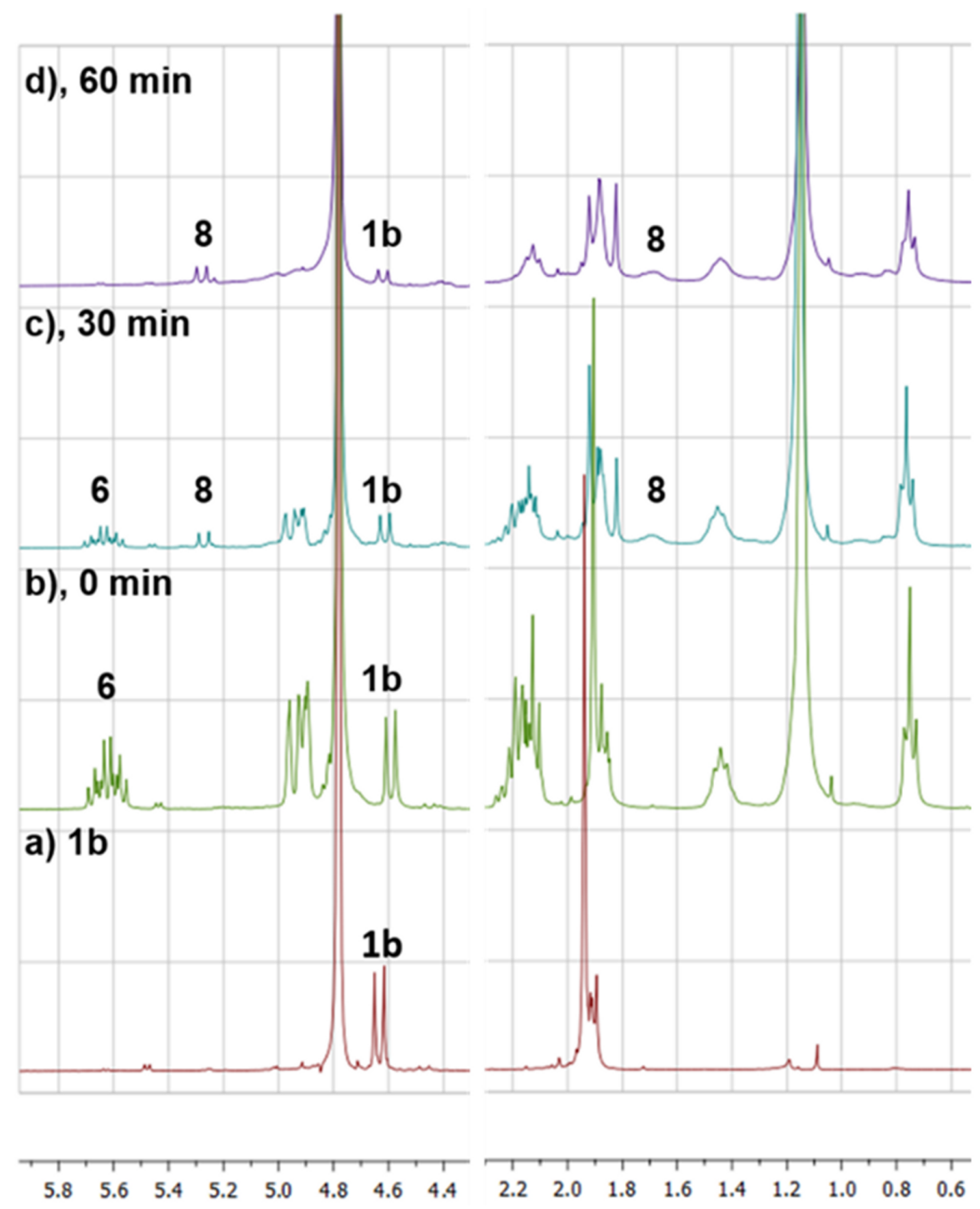

Figure 2: Periodic monitoring by ${ }^{1} \mathrm{H}$ NMR $\left(300 \mathrm{MHz}\right.$, DMF- $\left.d_{7}\right)$ of the formation of product 8 from a mixture compounds $1 \mathbf{b}$ and 6 . a) Spectrum of pure $1 \mathbf{b}$; b) through d) crude reaction mixture after 0,30 and 60 minutes of irradiation, respectively. 
progressively decreased in intensity with apparition of new signals corresponding to the new anomeric protons $\left(\delta_{\mathrm{H}}=5.26 \mathrm{ppm}\right)$ and the $\alpha-\mathrm{CH}_{2}$ of the thioether bond $\left(\delta_{\mathrm{H}}=1.70 \mathrm{ppm}\right)$. Compound 8 was isolated by column chromatography in $75 \%$ yield and no traces of starting material 6 were found. In addition, no intramolecular addition products neither mono-glycosylated compounds were observed.

\section{Preparation of vesicles upon hydration of a thin film of phospholipids and glycolipids}

Once synthesized, the compounds $\mathbf{5}$ and $\mathbf{8}$ bearing GlcNAc residues were used to produce giant vesicles (GVs) upon hydration with PBS (pH 7.4) by modifying reported procedures [28-
30]. GVs were prepared by hydrating a thin film containing 90:10 (mol \%) of those glycoconjugates in mixture with a natural phospholipid: 1-palmitoyl-2-oleoyl-sn-glycero-3-phosphocholine (POPC). As expected, the mixture once hydrated showed a high tendency to vesiculate (Figure 3, images a-e and h). Moreover, a thin layer of compounds $\mathbf{5}$ or $\mathbf{8}$ without POPC, hydrated in the same conditions, gave similar giant vesicles (Figure 3, images f,g and i). Microscopic observation suggested that those supramolecular assemblies microscopically resemble the well-known outer membrane vesicles (OMV) [1]. The tentative dissolution of compounds $\mathbf{5}-\mathbf{8}$ in PBS ( $\mathrm{pH}$ 7.4) produced a slightly turbid suspension, suggesting that those molecules formed a mixture of microscopically visible vesicles (diameter
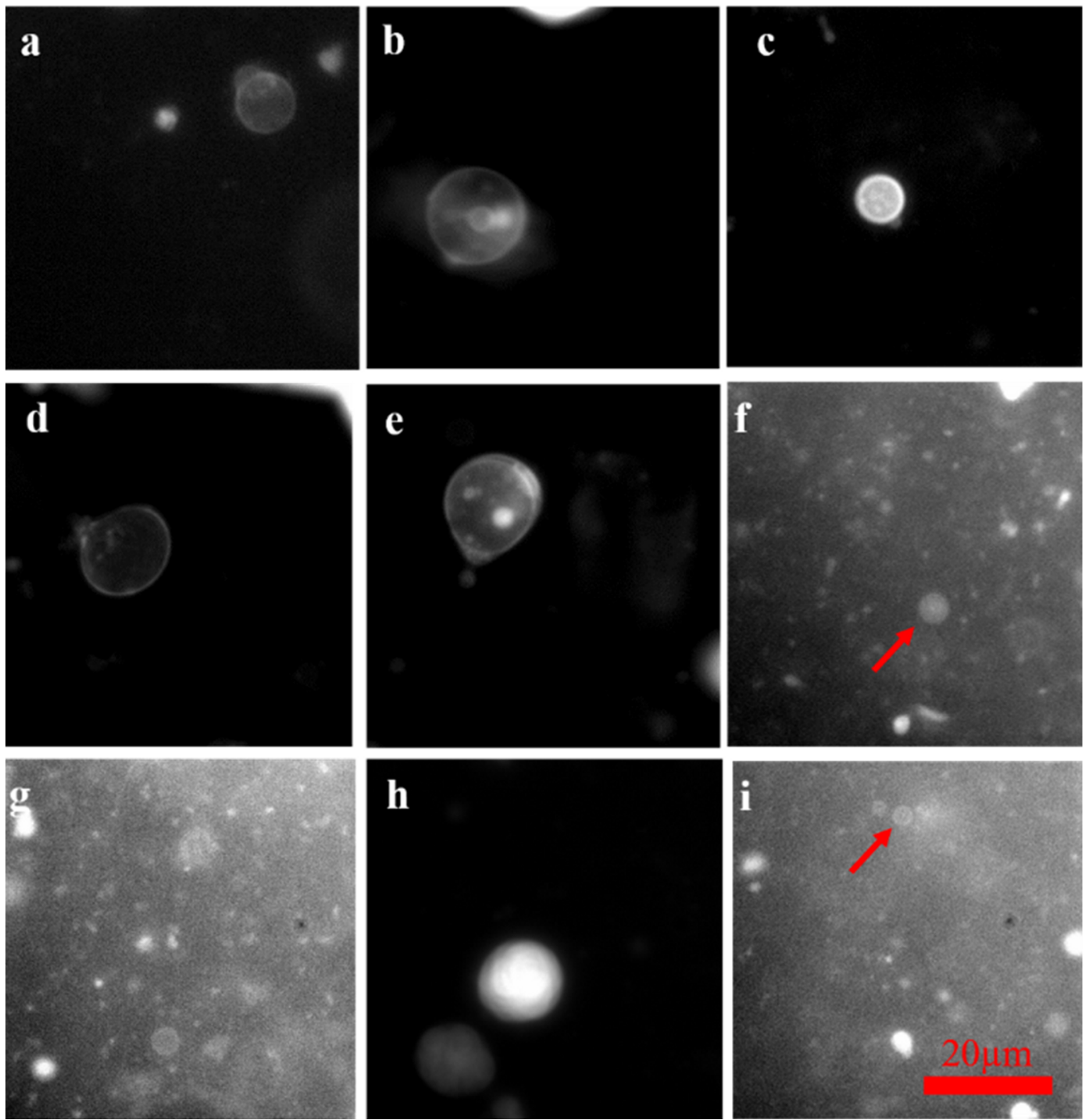

Figure 3: Micrographs of giant vesicles and lipid aggregates obtained from the gentle hydration (in PBS, pH 7.4) of compounds 8 and $\mathbf{5}$, alone and in binary and ternary mixtures with POPC. a-e) POPC/8, 9:1 molar ratio; fand g) pure 8; h) 5/8, 1:1 molar ratio; i) pure 5; All the samples were prepared with $1 \mathrm{mM}$ lipids and stained with NileRed ${ }^{\circledR}\left(1 \mathrm{mM}\right.$ in EtOH, $\left.1 \mu \mathrm{L}, \lambda_{\text {[excit] }}=561 \mathrm{~nm}\right)$ before the microscopic observation. Red arrows are used to indicate small GVs. The scale bar is $20 \mu \mathrm{m}$ for all micrographs in this figure. 
$>0.5 \mu \mathrm{m}$ ), small vesicles (diameter $<0.5 \mu \mathrm{m}$ ) and perhaps micelles (diameter in the nanometer range). However, due to our interest to study the interaction of OMV-like objects [1] we prepared giant vesicles resembling the OMV by using mixtures of fully synthetic compounds and natural occurring phospholipids. The vesicles showed stability over time; however, osmotic stress, sudden temperature change and accidental drying of the hosting solution inevitably cause the disruption of the supramolecular assembly [23]. Analyses under saline stress were not performed as the ultimate aim is to use of those OMV models under physiological conditions.

\section{Biological evaluation of the synthesized com- pounds}

Competitive enzyme-linked lectin assays (ELLA) were used to evaluate the binding properties of compounds $\mathbf{5}$ and $\mathbf{8}$ towards wheat germ agglutinin (WGA), a lectin from Triticum vulgaris that is specific for $\mathrm{N}$-acetylneuraminic acid and $\mathrm{N}$-acetylglucosamine. This assay consists in measuring the ability of the compounds to inhibit the binding of WGA horseradish peroxidaselabelled (WGA-HRP) to a GlcNAc-polyacrylamide conjugate following the procedure described in Figure 4.

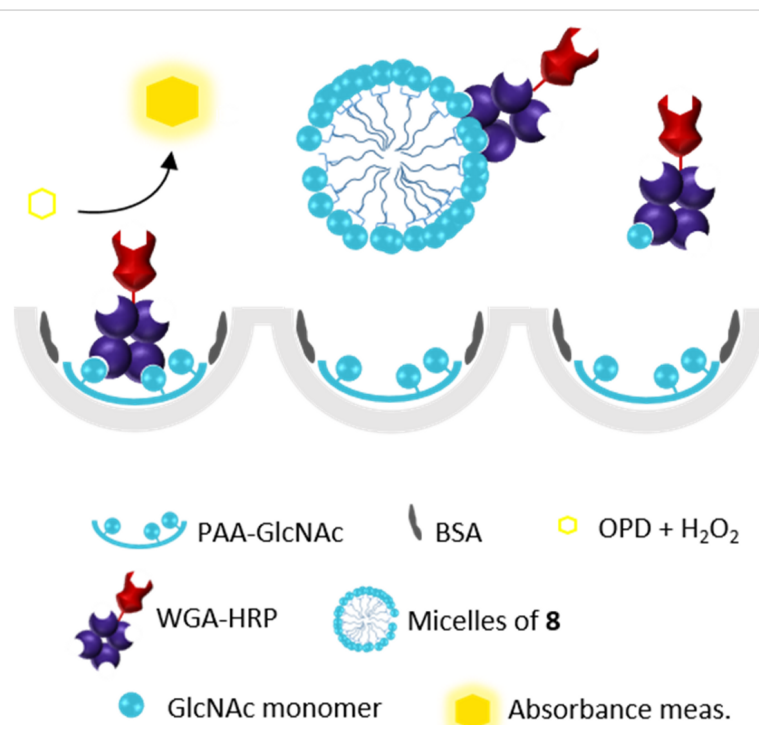

Figure 4: A simplified (and not in scale) representation of the ELLA assay, to study the interaction between GVs or micelles of compound 8 or $\mathbf{5}$ and WGA. OPD: O-phenylenediamine dihydrochloride; PAA: poly[N-(2-hydroxyethyl)acrylamide].

WGA is a homodimer in which each monomer is organized into four domains (A-D) containing adjacent "primary" (B and C) and "secondary" (A and D) domains binding sites with different affinities to GlcNAc [31]. The proximity of adjacent binding sites $(\approx 14 \AA)$ [32] makes this lectin an excellent candidate to investigate multivalent carbohydrate-protein interactions [33]. Although the scientific literature is rich of remarkable exam- ples of biologically active carbohydrate-based compounds with high affinity to lectins and with antibiotic activities [34], lectin recognition by $n$-alkyl thioglycoside liposomes remains unprecedented [33,34]. Moreover, the calculated distance between the two sugar moieties of compound 8 (up to $13 \AA$, Figure 6) and the presence of flexible arms make these compounds similar to other efficient multivalent glycoconjugates obtained by TEC of sugar thiols with different multivalent scaffolds such as octasilsesquioxanes [35], cyclopeptides [36,37] and polymers [38].

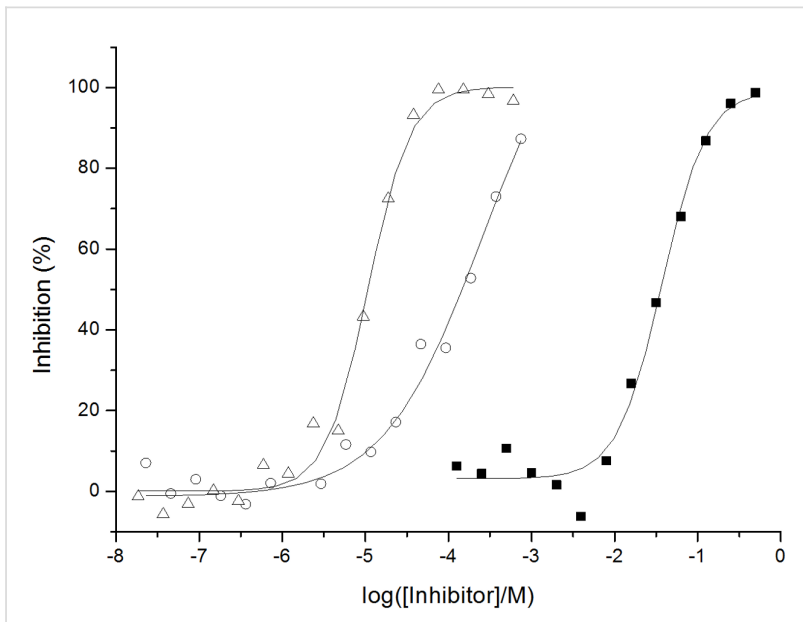

Figure 5: Inhibition curves for the binding of WGA-HRP to PAAGIcNAc by D-GIcNAc The symbols $(\bullet),(\triangle)$ and $(\circ)$ represent the monomer (GICNAc) and the lipophilic thioglycoconjugates 8 and $\mathbf{5}$, respectively.

Both compounds $\mathbf{5}$ and $\mathbf{8}$ showed low $\mathrm{IC}_{50}$ values (a tenth to some hundreds of micromolars) where the GlcNAc monomer displays only $35 \mathrm{mM}$ (Table 1). Compounds 4 and 7 bearing one and two glucose residues served as negative controls as WGA has no affinity towards glucose. This result clearly shows the high potential of the lipophilic $n$-alkyl thioglycoconjugates for lectine binding. In particular, compound $\mathbf{8}$ showed the highest inhibitory effect of this study with an $\mathrm{IC}_{50}$ of $11 \mu \mathrm{M}$ corresponding to a 3000 -fold improvement compared to the monomer control. This result suggests a higher participation of sugar units in the lectin binding for this compound.

Table 1: Inhibition of the adhesion of WGA-HRP to GIcNAc-coated microtiter plates as determined by ELLA ${ }^{a}$.

\begin{tabular}{lll} 
Compound & $\mathrm{IC}_{50}(\mu \mathrm{M})$ & $\mathrm{rp}^{\mathrm{b}}$ \\
\hline D-GlcNAc & 35000 & 1 \\
$\mathbf{5}$ & 142 & 246 \\
$\mathbf{8}$ & 11 & 3182 \\
\hline
\end{tabular}

${ }^{a}$ Experiments were performed in triplicate except for compound 5 . ${ }^{b} \mathrm{rp}$ : relative potency $=I C_{50}($ lipophilic thioglycoconjugate $) / I C_{50}(G \mid c N A c)$. 


\section{Docking calculation for model glycolipids}

To appreciate the possible binding of $4,5,7$ and $\mathbf{8}$ onto WGA, a docking simulation was performed using the crystal structure of WGA obtained in the presence of GlcNAc (PDB 2UVO) and of other GlcNAc derivatives (PDB 2X52 and 4AML). The docking experiments were performed using analogous molecules bearing acetate and butanoate alkyl chains (namely $\mathbf{4} \mathbf{C}_{2}$, $\mathbf{4} C_{4}, 5 C_{2}, 5 C_{4}, 7 C_{2}, 7 C_{4}, 8 C_{2}$ and $8 C_{4}$ according to the alkyl length, see Figures S5 and $\mathrm{S} 6$ in Supporting Information File 1) instead of the long alkyl chains, for calculation simplicity.

The docking protocol was validated using GlcNAc and Glc as ligands. In such a case, the poses found with GlcNAc were strictly identical to the ones observed in the crystal structure while no poses were obtained using Glc as ligand. Docking experiments using Glc derivatives $\mathbf{4} \mathbf{C}_{\mathbf{2}}, \mathbf{4} \mathbf{C}_{\mathbf{4}}, \mathbf{7} \mathbf{C}_{\mathbf{2}}$ and $\mathbf{7} \mathbf{C}_{\mathbf{4}}$ do not lead to any poses, suggesting, as observed in the ELLA experiments, that WGA do not bind them.

About half of the poses obtained from compounds $\mathbf{5} \mathbf{C}_{\mathbf{2}}$ and $\mathbf{5 C}_{\mathbf{4}}$ (bearing a single sugar moiety) were found on the primary (BC) and secondary (AD) binding sites with energies ranging from -4.5 to $-4.9 \mathrm{kcal} \mathrm{mol}^{-1}$ (pose A, Figure 6 and Supporting Information File 1, Figure S5) $[31,32,39,40]$. The binding of $\mathbf{8} \mathbf{C}_{\mathbf{2}}$ and $\mathbf{8 C}_{4}$ onto WGA lead to two main poses. The first one (energies ranging from -5.3 to $-6.2 \mathrm{kcal} \mathrm{mol}^{-1}$ ) corresponds to the binding of both GlcNAc moieties onto the secondary binding sites D2A1 and A2 (pose B, Figure 6). None of the poses were found to occupy primary binding sites as it was observed for $\mathbf{5 C}_{\mathbf{2}}$ and $\mathbf{5 C}_{\mathbf{4}}$. The first GlcNAc moiety of $\mathbf{8 C}_{\mathbf{2}}$ and $\mathbf{8 C}_{\mathbf{4}}$ interacts with Asp29A, Asp129B, Ser148B and Tyr159B and nearly superimposes with GlcNAc in the WGA crystalline structure (site D2A1). The second GlcNAc moiety is at the vicinity of Ser19A and Tyr30A residues (A2 binding site), therefore mimicking the binding of two GlcNAc molecules on WGA. The distance between the two GlcNAc residues is 11-12 $\AA$ [41]. The alkyl chains (acetyl or butyl) fit in the non-polar environment provided by Trp150B and by Gly158B or by the acyl moiety of Lys33A (pose B, Figure 6). Nevertheless, there is no obvious involvement of the ester bond in the binding of $\mathbf{8 C}_{2}$ or $\mathbf{8 C}_{\mathbf{4}}$ at these secondary sites. The other main poses of $\mathbf{8 C}_{\mathbf{2}}$ and $\mathbf{8 C}_{\mathbf{4}}$ present the ligands adopting a linear conformation in a cleft between both monomers of WGA with similar energies ( -5.3 to $-6.2 \mathrm{kcal} \mathrm{mol}^{-1}$, pose C, Figure 6 and Figure S6 in Supporting Information File 1). This cleft is defined by neutral residues Asn14A and Asn101B but also by the non-polar Leu16A and Ile155B that provide hydrophobic environment for the heptanol moiety in $\mathbf{8 C}_{\mathbf{2}}$ and $\mathbf{8 C}_{\mathbf{4}}$. This region of the protein also lacks charged residues that would prevent $\mathbf{8 C}_{\mathbf{2}}$ or $\mathbf{8 C}_{\mathbf{4}}$ from binding. GlcNAc moieties are proposed to interact with the hydroxy group of Ser8B and the carbonyl of Cys24A from one side and
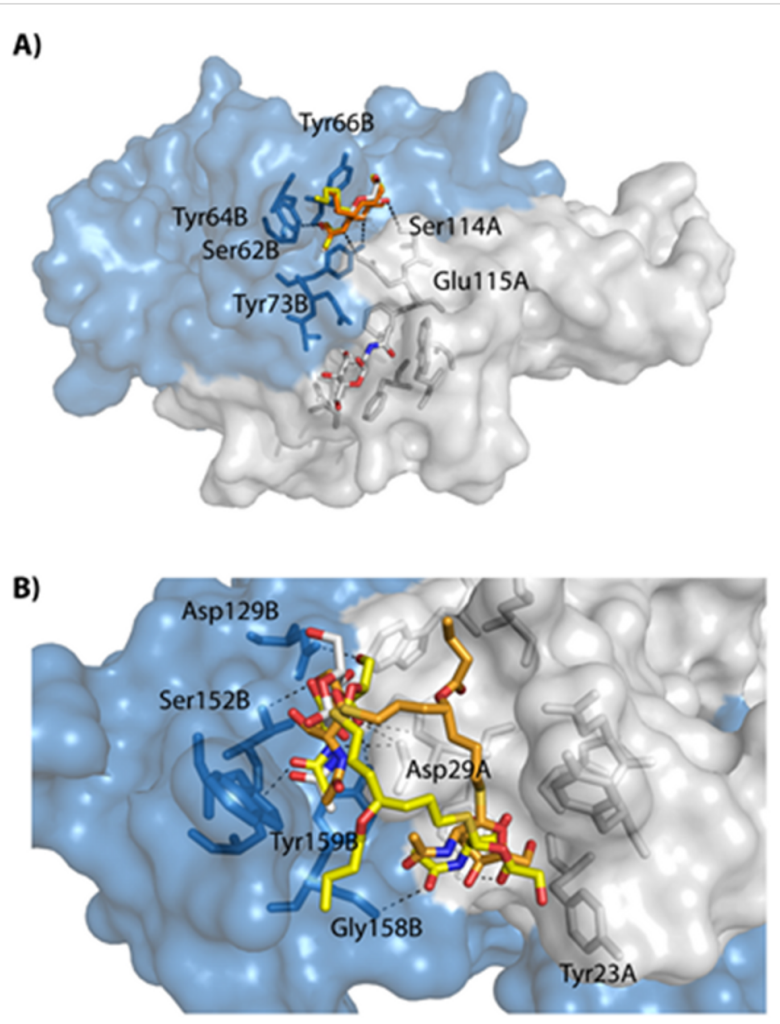

C)

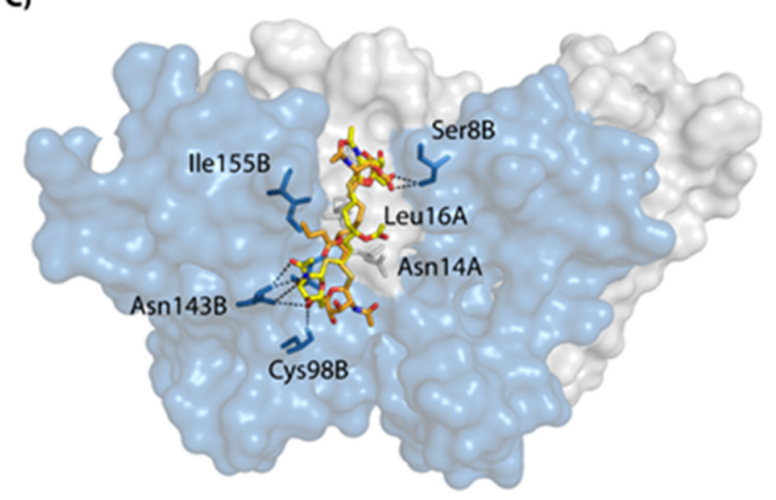

Figure 6: Main poses obtained from docking experiments. WGA (PDB 2UVO) surface is shown in white for monomer $A$ and in blue for monomer B. Residues within $4 \AA$ of the docked compound are in white stick representation. A) Representative poses obtained for $\mathbf{5} \mathbf{C}_{\mathbf{2}}$ (yellow sticks) and $\mathbf{5} \mathbf{C}_{\mathbf{4}}$ (orange sticks) at the $\mathrm{B} 1 \mathrm{C} 2$ primary site superimposed with co-crystallized GIcNAc (white sticks). B) Representative poses of $\mathbf{8} \mathrm{C}_{\mathbf{4}}$ (orange and yellow sticks) obtained at the D2A1 and A2 binding superimposed with co-crystalized GIcNAc (white sticks).

C) Representative poses of $\mathbf{8} C_{2}$ (yellow sticks) and $\mathbf{8} C_{4}$ (orange sticks) in the cleft between the two WGA monomers.

with Asn143B, the carbonyl of Cys98B or Asn14A on the other side. The alkyl chains of $\mathbf{8} \mathbf{C}_{\mathbf{2}}$ and $\mathbf{8} \mathbf{C}_{\mathbf{4}}$ are found close to Ile155B and head out of the cleft if a longer alkyl chain is used (as in 8). These observations suggest that the herein synthesized bidentate analogues of GlcNAc would interact with WGA differently than compounds bearing one sugar residue. The short distance between the two sugar moieties as well as the 
presence of the non-polar alkyl chains seems to prevent the binding to primary sites.

\section{Conclusion}

A series of glucose and $N$-acetyl glucosamine-based thioglycolipids were synthesized for the first time by using thiol-ene coupling in the absence of protecting groups and in good yields. Monosaccharides where selected on the basis of similar researches carried out in the field [38]. We reported a simplified access to $n$-alkyl thioglycosides as building blocks for the preparation of OMV models. The obtained $n$-alkyl thioglycosides were tested for the first time for lectin recognition and showed promising results, as their aggregates in PBS displayed micromolar affinity with WGA. In addition, we produced multilamellar giant vesicles of variable size from the glycolipids alone or in mixture with phospholipids. The vesicles we obtained showed similarities with OMV structures observed by Holst and co-workers (cf. Supporting Information File 1, Figure S4) [1]. This work suggests that mixtures of phospholipids such as POPC and small amounts of bioactive glycolipids should give a controlled bilayer. Such a construct could represent attractive carriers for vaccines once the sugar moiety of the glycolipid is substituted by $T_{\mathrm{n}}$ or $T_{\mathrm{f}}$ antigens $[42,43]$ or using natural glycolipids from Gram-negative bacteria such as lipid A [4]. This work represents the first step towards the formulation of an heterogeneous, stable systems (under biological conditions) that can be used for several biological purposes including synthetic vaccines, supramolecular adjuvants, glycolipid-phospholipid drug delivery systems and for the formulation of GVs that can be used as tools to bind to various bacterial lectins depending on the mono- or disaccharides used. As a first and relevant conclusion, in silico and in vitro studies demonstrated that two of those compounds, bearing one or two $\mathrm{N}$-acetyl glucosamine moieties are capable to bind strongly to the lectin WGA.

\section{Experimental \\ Materials and methods}

Myristoyl chloride was from TCI-Europe (Antwerp, Belgium) and used without further purification. 1-Palmitoyl-2-oleoyl-snglycero-3-phosphate (POPC) was from Avanti Polar Lipids (Alabaster, AL, USA). 2,3,4,6-Tetra- $O$-acetyl- $\alpha$-D-glucopyranosyl bromide and $N$-acetyl-D-glucosamine were from Carbosynth (San Diego, CA, USA). Wheat germ agglutinin (WGA), horseradish peroxidase-labelled WGA (WGA-HRP), bovine serum albumin (BSA) and SIGMA FAST $O$-phenylenediamine dihydrochloride (OPD) were from Sigma-Aldrich. Polymeric $N$-acetyl- $\beta$-D-glucosamine (PAA-GlcNAc) was from Lectinity Holding, Inc., Moscow. DPAP (2,2-dimethoxy-2phenylacetophenone) and all the other reagents were from Sigma-Aldrich (Merck KGaA, Darmstadt, Germany). Reaction solvents were from Fischer Scientific (Illkirch, France). Deuterated solvents for NMR were from Euriso-top (France). All sensitive reactions were carried out in oven-dried glassware under an inert argon atmosphere. Room temperature (rt) refers to $20-25^{\circ} \mathrm{C}$. All thiol-ene couplings were performed with a Philips UVA lamp irradiating at $365 \mathrm{~nm}$ (Mgc typ838 $150 \mathrm{~W}$, 6 tubes). Thin-layer chromatography (TLC) was carried out on aluminum sheets coated with silica gel 60 F254 (Merck, Kenilworth, USA). TLC plates were inspected by UV light $(\lambda=254 \mathrm{~nm})$ and developed by treatment with a mixture of $10 \% \mathrm{H}_{2} \mathrm{SO}_{4}$ in $\mathrm{EtOH} / \mathrm{H}_{2} \mathrm{O}(1: 1 \mathrm{v} / \mathrm{v})$, followed by heating. Electrospray-ionization mass spectra (ESIMS) were recorded using a Bruker Q-Tof Micromass spectrometer. NMR spectra were recorded in DMSO- $d_{6}, \mathrm{CDCl}_{3}, \mathrm{CD}_{3} \mathrm{OD}$ or DMF- $d_{7}$ on a Bruker Avance 300 spectrometer at 300 and $75 \mathrm{MHz}$ and on a Bruker Avance 400 at 400 and $100 \mathrm{MHz}$ for ${ }^{1} \mathrm{H}$, and ${ }^{13} \mathrm{C}$, respectively. The attached proton test experiment (APT) was performed to replace the ${ }^{13} \mathrm{C}$ experiment when required. Chemical shifts of solvents $\left(\mathrm{CDCl}_{3}: \delta_{\mathrm{H}}=7.26\right.$ and $\delta_{\mathrm{C}}=77.13 ; \mathrm{CD}_{3} \mathrm{OD}: \delta_{\mathrm{H}}=3.31$ and $\delta_{\mathrm{C}}=49.50$; DMF- $d_{7} \delta_{\mathrm{H}}=8.01$, and $\left.\delta_{\mathrm{C}}=163.15\right)$ served as internal references. Signal shapes and multiplicities are abbreviated as br (broad), s (singlet), d (doublet), t (triplet), q (quartet), quint (quintet) and $\mathrm{m}$ (multiplet). Where possible, a scalar coupling constant $J$ is given in hertz $(\mathrm{Hz})$. Optical rotations were measured as $\mathrm{CHCl}_{3}$ solutions on a JASCO P-1010 digital polarimeter and converted to specific rotations $[\alpha]_{\mathrm{D}}$. Micrographs were recorded with an inverted microscope (Zeiss LSM 800 ) equipped with a $50 \times$ objective through the AxioCam software. Micrographs were used without any graphical treatment and the image size was adjusted respecting the $x / y$ pixel proportions

\section{Synthesis of compounds 3-8}

Compound 3: A stirred solution of 1 a $(47 \mathrm{mg}, 0.24 \mathrm{mmol}$, 3 equiv), 2a (11.2 $\mathrm{mg}, 0.08 \mathrm{mmol}, 1$ equiv) and DPAP ( $7.71 \mathrm{mg}, 0.024 \mathrm{mmol}, 0.3$ equiv) in $\mathrm{MeOH}(660 \mu \mathrm{L})$ was irradiated at room temperature for $30 \mathrm{~min}$ and then concentrated. The residue was purified by silica flash chromatography (gradient: 100:0-80:20 $\mathrm{CHCl}_{3} / \mathrm{MeOH}$ v/v). Yield: 77\% (20.7 mg, $0.06 \mathrm{mmol}) ;[\alpha]_{\mathrm{D}}{ }^{25}+11.8\left(c 0.1, \mathrm{CHCl}_{3}\right) ;{ }^{1} \mathrm{H} \mathrm{NMR}$ $\left(300 \mathrm{MHz}, \mathrm{CDCl}_{3}\right) \delta_{\mathrm{H}} 5.35(\mathrm{~d}, J=4.6 \mathrm{~Hz}, 1 \mathrm{H}), 4.42(\mathrm{~d}, J=$ $9.4 \mathrm{~Hz}, 2 \mathrm{H}), 3.83$ (s, 2H), 3.56 (dd, $J=7.9 \mathrm{~Hz}, 2 \mathrm{H}), 3.44$ (s, $1 \mathrm{H}), 3.36(\mathrm{dd}, J=8.9 \mathrm{~Hz}, 2 \mathrm{H}), 2.67(\mathrm{t}, J=7.2 \mathrm{~Hz}, 2 \mathrm{H}), 1.58$ (dt, $J=7.4 \mathrm{~Hz}, 2 \mathrm{H}), 1.23(\mathrm{~s}, 12 \mathrm{H}), 0.85(\mathrm{t}, J=6.7 \mathrm{~Hz}, 3 \mathrm{H})$; ${ }^{13} \mathrm{C}$ NMR $\left(75 \mathrm{MHz}, \mathrm{CDCl}_{3}\right) \delta_{\mathrm{C}} 14.3,22.9,29.2,29.4,29.6$, 29.9, 30.3, 31.1, 61.7, 69.5, 72.9, 78.0, 79.7, 86.4; HRMS ( $\mathrm{m} / \mathrm{z})$ : $[\mathrm{M}+\mathrm{H}]^{+}$calcd for $\mathrm{C}_{16} \mathrm{H}_{32} \mathrm{O}_{5} \mathrm{~S}, 336.487$; found, 336.493 .

Compound 4: A stirred solution of 1a, $(50 \mathrm{mg}, 0.25 \mathrm{mmol}$, 3 equiv), $2 \mathbf{b}$ ( $16.4 \mathrm{mg}, 21 \mu \mathrm{L}, 0.085 \mathrm{mmol}, 1$ equiv) and DPAP (5.9 mg, $0.025 \mathrm{mmol}, 0.3$ equiv) in DMF $(1 \mathrm{~mL})$ was irradiated 
at room temperature for $30 \mathrm{~min}$ and then concentrated. The residue was purified by silica flash chromatography (gradient: 100:0-80:20 $\mathrm{CHCl}_{3} / \mathrm{MeOH}$ v/v). Yield: 55\% (20.3 mg, $0.047 \mathrm{mmol}$ ). Chemical analyses are in agreement with what was previously reported [44].

Compound 5: A stirred solution of glycosyl thiol 1b (49.8 mg, $0.21 \mathrm{mmol}, 3$ equiv), $2 \mathbf{b}$ ( $13.7 \mathrm{mg}, 0.07 \mathrm{mmol}, 1$ equiv) and DPAP ( $5.1 \mathrm{mg}, 0.02 \mathrm{mmol}, 0.3$ equiv) in DMF $(660 \mu \mathrm{L})$ was irradiated at room temperature for $30 \mathrm{~min}$ and then concentrated. The residue was purified by silica flash chromatography (gradient: 100:0-80:20 $\mathrm{CHCl}_{3} / \mathrm{MeOH} \mathrm{v} / \mathrm{v}$ ). Yield: $85 \%$ (25.8 mg, $0.06 \mathrm{mmol}) ;{ }^{1} \mathrm{H} \mathrm{NMR}(400 \mathrm{MHz}, \mathrm{MeOD}) \delta_{\mathrm{H}} 4.46$ (d, $J=12.0 \mathrm{~Hz}, 1 \mathrm{H}), 3.86(\mathrm{dd}, J=12.0 \mathrm{~Hz}, 1 \mathrm{H}), 3.72(\mathrm{t}, J=$ $12.0 \mathrm{~Hz}, 1 \mathrm{H}), 3.70-3.64(\mathrm{~m}, 2 \mathrm{H}), 3.32(\mathrm{t}, J=12.0 \mathrm{~Hz}, 1 \mathrm{H}), 3.22$ (t, $J=12.0 \mathrm{~Hz}, 1 \mathrm{H}$, partially masked by HOD signal), 2.70 (m, 2H) $1.97(\mathrm{~s}, 3 \mathrm{H}), 1.61(\mathrm{~m}, 2 \mathrm{H}), 1.29(\mathrm{~s}, 14 \mathrm{H}), 0.90(\mathrm{t}, J=$ $8.0 \mathrm{~Hz}, 3 \mathrm{H}) ;{ }^{13} \mathrm{C}$ NMR (100.0 MHz, MeOD) $\delta 12.9,21.6,22.3$, 25.6, 28.6, 28.9, 29.1, 29.2, 29.3-29.4, 54.9, 61.4, 70.6, 76.0, $80.8,84.3 ;[\alpha]_{\mathrm{D}}{ }^{25}+11.8\left(c 0.1, \mathrm{CHCl}_{3}\right) ; \operatorname{HRMS}(\mathrm{m} / \mathrm{z}):[\mathrm{M}+\mathrm{H}]^{+}$ calcd for $\mathrm{C}_{22} \mathrm{H}_{44} \mathrm{NO}_{5} \mathrm{~S}$, 434.2921; found, 434.2935.

Compound 6: Hepta-1,6-dien-4-ol [24,25] (500 mg, 4.5 mmol), myristoyl chloride $(2.9 \mathrm{~mL}, 10.7 \mathrm{mmol})$ and DMAP $(1.3 \mathrm{~g}$, $10.7 \mathrm{mmol}$ ) were dissolved in $10 \mathrm{~mL}$ of dry $\mathrm{CH}_{2} \mathrm{Cl}_{2}$. The solution was stirred for $16 \mathrm{~h}$, then transferred in a separation funnel and washed with saturated $\mathrm{NaHCO}_{3}(2 \times 50 \mathrm{~mL})$ and brine $(50 \mathrm{~mL})$, dried over $\mathrm{Na}_{2} \mathrm{SO}_{4}$ and concentrated. The crude mixture was purified on a column of silica (isocratic, $\mathrm{CH}_{2} \mathrm{Cl}_{2}$ ) from which 3 was obtained as a transparent oil. Yield: 78\% (1.12 g, $3.50 \mathrm{mmol}) .{ }^{1} \mathrm{H}$ NMR $\left(300 \mathrm{MHz}, \mathrm{CDCl}_{3}\right) \delta_{\mathrm{H}} 5.80-5.66(\mathrm{~m}$, $2 \mathrm{H}), 5.08$ (d, $J=7.4 \mathrm{~Hz}, 2 \mathrm{H}), 5.03$ (br s, 2H), 4.95 (dd, $J=$ 12.4, $5.9 \mathrm{~Hz}, 1 \mathrm{H}), 2.34-2.30(\mathrm{~m}, 4 \mathrm{H}), 2.23(\mathrm{t}, J=8.3 \mathrm{~Hz}, 2 \mathrm{H})$, $1.63-1.57(\mathrm{~m}, 2 \mathrm{H}), 1.25$ (br s, 20H), 0.87 (t, $J=6.7 \mathrm{~Hz}, 3 \mathrm{H})$; ${ }^{13} \mathrm{C}$ NMR $\left(75 \mathrm{MHz}, \mathrm{CDCl}_{3}\right) \delta_{\mathrm{C}} 14.1,22.6,25.0,29.1,29.2$, 29.3, 29.4, 29.5-29.7, 31.9, 34.5, 38.0, 71.9, 117.7, 133.6, 173.3; HRMS $(\mathrm{m} / \mathrm{z}):[\mathrm{M}+\mathrm{H}]^{+}$calcd for $\mathrm{C}_{21} \mathrm{H}_{38} \mathrm{O}_{2}, 345.2769$; found, 345.2764 .

Compound 7: A stirred solution of $\mathbf{1 a}(117.6 \mathrm{mg}, 0.6 \mathrm{mmol}$, 6 equiv $(3 \times$ site $), 6(34.6 \mathrm{mg}, 0.1 \mathrm{mmol}, 1$ equiv) and DPAP $(15.0 \mathrm{mg}, 0.06 \mathrm{mmol}, 0.6$ equiv) in DMF $(660 \mu \mathrm{L})$ was irradiated at room temperature for $60 \mathrm{~min}$ and then concentrated. The residue was purified by silica flash chromatography (gradient: 100:0-80:20 $\mathrm{CHCl}_{3} / \mathrm{MeOH} \mathrm{v} / \mathrm{v}$ ). Yield: 75\% (51.5 mg, $0.07 \mathrm{mmol}) .{ }^{1} \mathrm{H}$ NMR $\left(400 \mathrm{MHz}, \mathrm{CD}_{3} \mathrm{OD}\right) \delta_{\mathrm{H}}(4.46(\mathrm{~d}, J=$ $10.3 \mathrm{~Hz}, 2 \mathrm{H}), 3.87(\mathrm{dd}, J=12.0,2.2 \mathrm{~Hz}, 2 \mathrm{H}), 3.73(\mathrm{dd}, J=$ $10.3,6.2 \mathrm{~Hz}, 2 \mathrm{H}) 3.71-3.66(\mathrm{~m}, 2 \mathrm{H}), 3.65-3.63(\mathrm{~m}, 2 \mathrm{H}), 3.54$ $(\mathrm{t}, J=6.7 \mathrm{~Hz}, 2 \mathrm{H}), 3.45-3.40(\mathrm{~m}, 2 \mathrm{H}), 3.29-3.25(\mathrm{~m}, 4 \mathrm{H})$, 2.78-2.61 (m, 2H), 2.04-1.55 (m, 2H) 1.66-1.48 (m, 2H), 1.27 (br s, $10 \mathrm{H}), 0.87(\mathrm{t}, J=6.0 \mathrm{~Hz}, 3 \mathrm{H}) ;{ }^{13} \mathrm{C} \mathrm{NMR}(100 \mathrm{MHz}$,
$\left.\mathrm{CD}_{3} \mathrm{OD}\right) \delta_{\mathrm{C}} 13.0,22.3,25.5,28.9,29.1,29.2,29.3,29.4,29.5$, $31.7,32.3,33.3,54.9,61.6,70.6,76.0,80.8,84.3,172.1 ;[\alpha]_{\mathrm{D}}{ }^{25}$ 0.37 ( c 0.1, MeOH); HRMS $(m / z):[\mathrm{M}+\mathrm{Na}]^{+}$calcd for $\mathrm{C}_{33} \mathrm{H}_{62} \mathrm{NaO}_{12} \mathrm{~S}_{2}, 736.3502$; found, 736.3508.

Compound 8: A stirred solution of $\mathbf{1 b}(142.2 \mathrm{mg}, 0.6 \mathrm{mmol}), \mathbf{6}$ (34.7 mg, $0.1 \mathrm{mmol}, 1$ equiv) and DPAP (15.0 mg, $0.06 \mathrm{mmol}$, 0.6 equiv) in DMF $(660 \mu \mathrm{L})$ was irradiated at room temperature for $120 \mathrm{~min}$ and then concentrated. The residue was purified by silica flash chromatography (gradient: 100:0-75:25 $\left.\mathrm{CHCl}_{3} / \mathrm{MeOH} \mathrm{v} / \mathrm{v}\right)$. Yield: 40\% (31.8 mg, $\left.0.04 \mathrm{mmol}\right)$. ${ }^{1} \mathrm{H}$ NMR $\left(300 \mathrm{MHz}, \mathrm{CD}_{3} \mathrm{OD}\right) \delta_{\mathrm{H}} 5.34(\mathrm{~m}, 4 \mathrm{H}), 5.08(\mathrm{~m}, 1 \mathrm{H})$, $4.34-4.21(\mathrm{~m}, 2 \mathrm{H}), 3.71(\mathrm{~d}, J=4.0 \mathrm{~Hz}, 2 \mathrm{H}), 2.35-2.21(\mathrm{~m}, 4 \mathrm{H})$, $2.00(\mathrm{~d}, J=8.0 \mathrm{~Hz}, 4 \mathrm{H}), 1.61(\mathrm{~d}, J=4.0 \mathrm{~Hz}, 4 \mathrm{H}), 1.27(\mathrm{~d}, J=$ $16.1 \mathrm{~Hz}, 34 \mathrm{H}), 0.87(\mathrm{t}, J=8.0 \mathrm{~Hz}, 6 \mathrm{H}) ;{ }^{13} \mathrm{C} \mathrm{NMR}(75 \mathrm{MHz}$, $\left.\mathrm{CDCl}_{3}\right) \delta_{\mathrm{C}} 22.7,24.8,24.9,25.6,27.0,27.1,27.2,29.0-29.2$, 29.3, 29.4, 29.7, 29.8, 31.9, 34.0, 34.3, 61.5, 62.0, 66.0, 72.1, $129.7,130.0,173.4,173.8,173.9 ;[\alpha]_{\mathrm{D}}{ }^{25} 0.31(c 0.1, \mathrm{MeOH})$; HRMS $(m / z)$ calcd for $\mathrm{C}_{37} \mathrm{H}_{68} \mathrm{~N}_{2} \mathrm{O}_{12} \mathrm{~S}_{2}, 796,4214$; found, 796,4222 .

Preparation and observation of giant vesicles: Giant vesicles (GVs) were prepared by the natural swelling method [23]. Lipids (mixture of commercial POPC and $n$-alkyl thioglycosides 5 or 8) were dissolved in methanol (typically, $2 \mathrm{~mL}$ ) in a $10 \mathrm{~mL}$ round-bottom flask. The solvent was completely evaporated under reduced pressure using a rotatory evaporator. The resulting thin lipid film was further dried for 180 minutes at $1 \mathrm{mbar} / 25^{\circ} \mathrm{C}$, and then hydrated for 16 hours - without shaking - with the aqueous buffer, termed "I-solution" (composed of $200 \mathrm{mM}$ sucrose in $50 \mathrm{mM}$ of PBS buffer, $\mathrm{pH}$ 7.4) to obtain an overall 1-2 mM lipid concentration. The hydration temperature was $25{ }^{\circ} \mathrm{C}$. Three volumes of the thus obtained GVs were diluted with one volume of an aqueous isotonic buffer solution termed "O-solution" (composed of $200 \mathrm{mM}$ glucose in $50 \mathrm{mM}$ of PBS buffer, $\mathrm{pH} \mathrm{7.4)} \mathrm{and} \mathrm{centrifuged} \mathrm{at} \mathrm{5,000} \mathrm{rpm} \mathrm{for}$ 10 minutes in a bench-top Eppendorf mini-centrifuge. GVs were pelleted down in the Eppendorf tube due to the density difference between the I-solution and the O-solution. The supernatant was carefully removed, and the pellet was re-suspended in $100 \mu \mathrm{L}$ of fresh O-solution. Each sample was stained with a Nile $\operatorname{Red}^{\circledR}$ solution ( $1 \mathrm{mM}$ in DMSO, $1 \mu \mathrm{L}$ ) before microscopic observation.

Enzyme-linked lectin assays: 96-well microtiter NuncImmuno plates (Maxi-Sorp) were coated with PAA-GlcNAc ( $100 \mu \mathrm{L}$ per well, diluted from a stock solution of $5 \mu \mathrm{g} \mathrm{mL}{ }^{-1}$ in $50 \mathrm{mM}$ carbonate buffer $\mathrm{pH} 9.6$ ) for $1 \mathrm{~h}$ at $37^{\circ} \mathrm{C}$. The wells were then washed with T-PBS $(3 \times 100 \mu \mathrm{L}$ per well, PBS pH 7.4 containing $0.05 \%(\mathrm{v} / \mathrm{v})$ Tween 20$)$. This washing procedure was repeated after each incubation step. The coated microtiter 
plates were then blocked with BSA in PBS $(3 \% \mathrm{w} / \mathrm{v}, 1 \mathrm{~h}$ at $37^{\circ} \mathrm{C}, 100 \mu \mathrm{L}$ per well). Serial two-fold dilutions of each inhibitor were pre-incubated $1 \mathrm{~h}$ at $37^{\circ} \mathrm{C}$ in PBS-DMSO (9:1 v/v, $60 \mu \mathrm{L}$ per well) in the presence of WGA-HRP $(60 \mu \mathrm{L})$ at the desired concentration. The above solutions $(100 \mu \mathrm{L})$ were then transferred to the blocked microtiter plates which were incubated for $1 \mathrm{~h}$ at $37^{\circ} \mathrm{C}$. After incubation, the plates were washed with T-PBS $(3 \times 100 \mu \mathrm{L}$ per well $)$ and then the color was developed using OPD (100 $\mu \mathrm{L}$ per well, $0.4 \mathrm{mg} \mathrm{mL}^{-1}$ in $0.05 \mathrm{M}$ phosphate-citrate buffer) and urea hydrogen peroxide $\left(0.4 \mathrm{mg} \mathrm{mL}^{-1}\right)$. The reaction was stopped after $10 \mathrm{~min}$ by adding $\mathrm{H}_{2} \mathrm{SO}_{4}(30 \% \mathrm{v} / \mathrm{v}, 50 \mu \mathrm{L}$ per well) and the absorbance was measured at $490 \mathrm{~nm}$. The percentage of inhibition was determined using the following equation, where $\mathrm{A}$ is absorbance. $\%$ Inhibition $=[(\mathrm{A}($ no inhibitor $)-\mathrm{A}($ with inhibitor $) / \mathrm{A}$ (no inhibitor $)] \times 100$. The percent of inhibition was plotted against the logarithm of the concentration of the sugar derivatives. The sigmoidal curves were fitted and the concentration at $50 \%$ inhibition of WGA-HRP binding to PAA-GlcNAc coated plates was determined $\left(\mathrm{IC}_{50}\right)$.

Docking experiments: WGA structure was obtained from the Protein Data Bank (2UVO) and unbound ligands (water, GlcNAc, glycerol and pyroglutamic acid) were removed. PDB files for compounds $4 C_{2}, 4 C_{4}, 5 C_{2}, 5 C_{4}, 7 C_{2}, 7 C_{4}, 8 C_{2}$ and $\mathbf{8 C}_{\mathbf{4}}$ were prepared using OpenBabel (version 2.4.1). Docking was performed using autodock vina implemented in the Samson software (version beta 0.7.0, NANO-D Inria, https:// www.samson-connect.net $)$. A grid $(60 \times 60 \times 60 \AA)$ including the whole protein was used and 20 poses leading to the lowest energies were kept as significant. Pictures were prepared using PyMOL (version 0.99rc6, DeLano Scientific, San Carlos, CA, 700).

\section{Supporting Information}

\section{Supporting Information File 1}

Additional Figures S1-S6 and spectra of synthesized glycolipids and starting materials.

[https://www.beilstein-journals.org/bjoc/content/ supplementary/1860-5397-15-90-S1.pdf]

\section{Acknowledgements}

Michele Fiore warmly thanks Dr. Sébastian Vidal (ICBMS, LCO2-Glyco) that encouraged exploring in this research field. Dr. Beatrice Pelotier is gratefully acknowledged for the analytical sample of the compound hepta-1,6-dien-4-ol given. The students of the class M1 "Fonctionnalisation en synthèse organique (CHM1182M)" are gratefully acknowledged for their support in the large-scale preparation of hepta-1,6-dien-4-ol.
The University of Lyon, "Claude Bernard" Lyon 1 and all the members of ICBMS/LCO2-glyco and the support from the BQR grant (2014) are gratefully acknowledged as well. This work is dedicated to the memory of Océane Fiore (2015-2017).

\section{ORCID ${ }^{\circledR}$ iDs}

Dimitri Fayolle - https://orcid.org/0000-0002-1543-136X Nathalie Berthet - https://orcid.org/0000-0002-3479-1918 Bastien Doumeche - https://orcid.org/0000-0003-3458-1029 Olivier Renaudet - https://orcid.org/0000-0003-4963-3848 Peter Strazewski - https://orcid.org/0000-0001-8540-3279 Michele Fiore - https://orcid.org/0000-0001-8176-9249

\section{References}

1. Holst, J.; Martin, D.; Arnold, R.; Huergo, C. C.; Oster, P.; O'Hallahan, J.; Rosenqvist, E. Vaccine 2009, 27 (Suppl. 2), B3-B12. doi:10.1016/j.vaccine.2009.04.071

2. Feiring, B.; Fuglesang, J.; Oster, P.; Næss, L. M.; Helland, O. S.; Tilman, S.; Rosenqvist, E.; Bergsaker, M. A. R.; Nøkleby, H.; Aaberge, I. S. Clin. Vaccine Immunol. 2006, 13, 790-796. doi:10.1128/cvi.00047-06

3. Jackson, C.; Lennon, D. R.; Sotutu, V. T. K.; Yan, J.; Stewart, J. M.; Reid, S.; Crengle, S.; Oster, P.; Ypma, E.; Aaberge, I.; Mulholland, K.; Martin, D. R. Arch. Dis. Child. 2009, 94, 745-751. doi:10.1136/adc.2007.132571

4. Molinaro, A.; Holst, O.; Di Lorenzo, F.; Callaghan, M.; Nurisso, A.; D'Errico, G.; Zamyatina, A.; Peri, F.; Berisio, R.; Jerala, R.; Jiménez-Barbero, J.; Silipo, A.; Martín-Santamaría, S. Chem. - Eur. J. 2015, 21, 500-519. doi:10.1002/chem.201403923

5. Global Vaccine Action Plan 2011-2020, World Health Organization: Geneva, 2012.

6. Nativi, C.; Renaudet, O. ACS Med. Chem. Lett. 2014, 5, 1176-1178. doi: $10.1021 / \mathrm{ml} 5003794$

7. Collins, B. S. Discovery Med. 2011, 12, 7.

8. Robyt, J. F. Essentials of Carbohydrate chemistry; Springer Science \& Business media, 2012.

9. Taylor, M. E.; Drickamer, K. Introduction to glycobiology; Oxford University Press: New York, USA, 2006.

10. El-Sukkary, M. M. A.; Syed, N. A.; Aiad, I.; Helmy, S. M.; El-Azab, W. I. M. Tenside, Surfactants, Deterg. 2009, 46, 311-316. doi:10.3139/113.110037

11. Matsson, M. K.; Kronberg, B.; Claesson, P. M. Langmuir 2004, 20 , 4051-4058. doi:10.1021/la035959p

12. Marino, C.; Mariño, K.; Miletti, L.; Manso Alves, M. J.; Colli, W.; de Lederkremer, R. M. Glycobiology 1998, 8, 901-904. doi:10.1093/glycob/8.9.901

13. Davis, C. B.; Hartnell, R. D.; Madge, P. D.; Owen, D. J.; Thomson, R. J.; Chong, A. K. J.; Coppel, R. L.; von Itzstein, M. Carbohydr. Res. 2007, 342, 1773-1780. doi:10.1016/j.carres.2007.04.027

14. Samoshin, A. V.; Dotsenko, I. A.; Samoshina, N. M.; Franz, A. H.; Samoshin, V. V. Int. J. Carbohydr. Chem. 2014, No. 941059. doi:10.1155/2014/941059

15. van Doren, H. A.; van der Geest, R.; Kellogg, R. M.; Wynberg, H. Carbohydr. Res. 1989, 194, 71-77. doi:10.1016/0008-6215(89)85007-4 
16. van Doren, H. A.; van der Geest, R.; van Bolhuis, F.; Kellogg, R. M.; Wynberg, H. Carbohydr. Res. 1989, 194, 79-86. doi:10.1016/0008-6215(89)85008-6

17. Kumar, V.; Taxak, N.; Jangir, R.; Bharatam, P. V.; Kartha, K. P. R. J. Org. Chem. 2014, 79, 3427-3439. doi:10.1021/jo5001753

18. Dondoni, A. Angew. Chem., Int. Ed. 2008, 47, 8995-8997. doi:10.1002/anie.200802516

19. Dondoni, A.; Marra, A. Chem. Soc. Rev. 2012, 41, 573-586. doi:10.1039/c1cs15157f

20. McSweeney, L.; Dénès, F.; Scanlan, E. M. Eur. J. Org. Chem. 2016, 2080-2095. doi:10.1002/ejoc.201501543

21. Zhou, C. Y.; Wu, H.; Devaraj, N. K. Chem. Sci. 2015, 6, 4365-4372. doi:10.1039/c5sc00653h

22. Goyard, D.; Shiao, T. C.; Fraleigh, N. L.; Vu, H.-Y.; Lee, H.; Diaz-Mitoma, F.; Le, H.-T.; Roy, R. J. Mater. Chem. B 2016, 4, 4227-4233. doi:10.1039/c6tb00344c

23. Fiore, M.; Marra, A.; Dondoni, A. J. Org. Chem. 2009, 74, 4422-4425. doi:10.1021/jo900514w

24. Dallanegra, R.; Pilgrim, B. S.; Chaplin, A. B.; Donohoe, T. J.; Weller, A. S. Dalton Trans. 2011, 40, 6626. doi:10.1039/c1dt10503e

25. Glachet, T.; Fache, F.; Pelotier, B.; Piva, O. Synthesis 2017, 49, 5197-5202. doi:10.1055/s-0036-1588521

26. Roodsari, F. S.; Wu, D.; Pum, G. S.; Hajdu, J. J. Org. Chem. 1999, 64, 7727-7737. doi:10.1021/jo990414e

27. Reactions performed in $\mathrm{MeOH}$ or MeOD and DMF or DMF- $d_{7}$ gave similar and reproducible yields. Although the conversion observed by ${ }^{1} \mathrm{H}$ NMR was always $100 \%$, with complete consumption of the starting alkene, we encountered difficulties in the flash chromatography purification step due to the amphiphilic character of the molecule and its high affinity with the silica gel.

28. Fiore, M.; Madanamoothoo, W.; Berlioz-Barbier, A.; Maniti, O.; Girard-Egrot, A.; Buchet, R.; Strazewski, P. Org. Biomol. Chem. 2017, 15, 4231-4240. doi:10.1039/c7ob00708f

29. Fayolle, D.; Altamura, E.; D’Onofrio, A.; Madanamothoo, W.; Fenet, B.; Mavelli, F.; Buchet, R.; Stano, P.; Fiore, M.; Strazewski, P. Sci. Rep. 2017, 7, 18106. doi:10.1038/s41598-017-18053-y

30. Fayolle, D.; Fiore, M.; Stano, P.; Strazewski, P. PLoS One 2018, 13, e0192975. doi:10.1371/journal.pone.0192975

31. Wright, C. S. J. Biol. Chem. 1992, 267, 14345.

32. Wright, C. S. J. Mol. Biol. 1987, 194, 501-529. doi:10.1016/0022-2836(87)90678-4

33. Cecioni, S.; Imberty, A.; Vidal, S. Chem. Rev. 2015, 115, 525-561. doi:10.1021/cr500303t

34. Bernardi, A.; Jiménez-Barbero, J.; Casnati, A.; De Castro, C.; Darbre, T.; Fieschi, F.; Finne, J.; Funken, H.; Jaeger, K.-E.; Lahmann, M.; Lindhorst, T. K.; Marradi, M.; Messner, P.; Molinaro, A.; Murphy, P. V.; Nativi, C.; Oscarson, S.; Penadés, S.; Peri, F.; Pieters, R. J.; Renaudet, O.; Reymond, J.-L.; Richichi, B.; Rojo, J.; Sansone, F.; Schäffer, C.; Turnbull, W. B.; Velasco-Torrijos, T.; Vidal, S.; Vincent, S.; Wennekes, T.; Zuilhof, H.; Imberty, A. Chem. Soc. Rev. 2013, 42, 4709-4727. doi:10.1039/c2cs35408j

35. Lo Conte, M.; Staderini, S.; Chambery, A.; Berthet, N.; Dumy, P.; Renaudet, O.; Marra, A.; Dondoni, A. Org. Biomol. Chem. 2012, 10, 3269. doi:10.1039/c2ob07078b

36. Fiore, M.; Berthet, N.; Marra, A.; Gillon, E.; Dumy, P.; Dondoni, A.; Imberty, A.; Renaudet, O. Org. Biomol. Chem. 2013, 11, 7113. doi:10.1039/c3ob41203b

37. Fiore, M.; Daskhan, G. C.; Thomas, B.; Renaudet, O. Beilstein J. Org. Chem. 2014, 10, 1557-1563. doi:10.3762/bjoc.10.160
38. Fiore, M.; Berthet, N.; Renaudet, O.; Barbier, V. Med. Chem. Commun. 2014, 5, 1202-1207. doi:10.1039/c4md00097h

39. Wright, C. S.; Kellogg, G. E. Protein Sci. 1996, 5, 1466-1476. doi:10.1002/pro.5560050803

40. Schwefel, D.; Maierhofer, C.; Beck, J. G.; Seeberger, S.; Diederichs, K.; Möller, H. M.; Welte, W.; Wittmann, V. J. Am. Chem. Soc. 2010, 132, 8704-8719. doi:10.1021/ja101646k

41. This value is comparable with distances previously observed in WGA crystals soaked in divalent and tetravalent GlcNAc ligands.

42. Fiore, M.; Thomas, B.; Duléry, V.; Dumy, P.; Renaudet, O. New J. Chem. 2013, 37, 286-289. doi:10.1039/c2nj40972k

43. Richichi, B.; Thomas, B.; Fiore, M.; Bosco, R.; Qureshi, H.; Nativi, C.; Renaudet, O.; BenMohamed, L. Angew. Chem., Int. Ed. 2014, 53, 11917-11920. doi:10.1002/anie.201406897

44. Saito, S.; Furumoto, T.; Ochiai, M.; Hosono, A.; Hoshino, H.; Haraguchi, U.; Ikeda, R.; Shimada, N. Eur. J. Med. Chem. 1996, 31 , 365-381. doi:10.1016/0223-5234(96)89163-x

\section{License and Terms}

This is an Open Access article under the terms of the Creative Commons Attribution License (http://creativecommons.org/licenses/by/4.0). Please note that the reuse, redistribution and reproduction in particular requires that the authors and source are credited.

The license is subject to the Beilstein Journal of Organic Chemistry terms and conditions: (https://www.beilstein-journals.org/bjoc)

The definitive version of this article is the electronic one which can be found at: doi: $10.3762 /$ bjoc. 15.90 